\title{
MISTERIUM PASCHALNE CHRYSTUSA W INTEGRALNYM UJĘCIU WACŁAWA HRYNIEWICZA OMI
}

Odkupienie dokonane przez Jezusa Chrystusa to największe wydarzenie w historii zbawienia, przez które człowiek uzyskał zdolność upodobnienia się do Boga. Według myśli lubelskiego teologa, misterium to nie ogranicza się jedynie do samego wydarzenia śmierci i zmartwychwstania, ale jest ściśle związane, wręcz uwarunkowane wcieleniem oraz zesłaniem Ducha Świętego.

Misterium paschalne oznacza tajemnicę Bożego planu zbawienia, której punktem szczytowym jest wydarzenie Jezusa Chrystusa - całe jego życie, a zwłaszcza kulminacyjny moment męki, śmierci i zmartwychwstania. Nie można go zatem ograniczać tylko do śmierci i zmartwychwstania Chrystusa (sens węższy). Wyraża właściwie całą tajemnicę zbawienia (sens szeroki), która obejmuje: jej przygotowanie w Starym Testamencie; urzeczywistnienie w Chrystusie; kontynuację w Kościele; uwieńczenie w paruzji. Oczywiście dzieło Chrystusa historycznego i uwielbionego jest szczytowym wydarzeniem, które dosięga ludzi żyjących przed wcieleniem Logosu, jest kontynuowane w Kościele i stanowi antycypację czasów eschatycznych. Misterium jest jedno i niepodzielne i jako takie rozszerza się na poszczególne wydarzenia, które stanowią całość.'

I Chcąc sprecyzować pojęcie „misterium” W. Hryniewicz, przytacza zdania Ojców, dla których termin ten oznacza: wydarzenia Starego Testamentu będące typem wydarzeń Nowego Testamentu; samego Chrystusa Boga-Człowieka i poszczególne wydarzenia z jego życia; Pismo Swięte; Kościól; kult chrześcijański. Stopniowo słowo misterium zaczęto odnosić do sakramentów, w których pod zewnętrznym, symbolicznym znakiem ukryta jest rzeczywistość zbawcza: misterium Paschy. W Kościele przez sakramenty uobecniają się zbawcze dzieła Chrystusa. Przez „Paschę” Hryniewicz rozumie nie tylko cierpienie (passio), bolesną mękę i śmierć, ale też przejście (transitus) Chrystusa ze śmierci do nowego życia; por. W. H r y n i e w i c z, Chrystus nasza Pascha. Zarys chrześcijańskiej teologii paschalnej, t. I, Lublin 1982, s. 52-63 (dalej: Pascha I); zob. także t e n ż e, Soteriologia paschalis. Próba interpretacji zbawienia $w$ świetle kategorii paschalnych, AK 98(1981) z. 433, s. 167-181; S. C z e r w i k, Paschalne Misterium, w: M. R u s e c k i i in. (red.), Leksykon Teologii Fundamentalnej, Kraków 2002, s. 895-902. 
Potrzeba zaakcentowania integralnego ujęcia misterium paschalnego Chrystusa jest zasadniczym źródłem inspiracji i celem podjęcia tematu prezentowanego w niniejszym artykule. Wybór myśli teologicznej Wacława Hryniewicza jest wtórny, ale nie przypadkowy, ponieważ nikt inny na gruncie polskiej teologii nie poświęcił temu zagadnieniu tak wiele uwagi. Co więcej, jego trzytomowy Zarys teologii paschalnej, ${ }^{2}$ stanowiący główne źródło prezentowanych tu treści, nie jest abstrakcyjną teorią. Stanowi głębokie przemyślenie centralnego misterium wiary, godny zauważenia egzemplarz teologii żywej i otwartej.

W niniejszym artykule przedstawia się Hryniewiczową wykładnię integralnie rozumianego misterium paschalnego Chrystusa. W trzech kolejnych rozdziałach odsłania się kolejno jego myśl związana z interpretacją trzech wymiarów owego misterium: inkarnacyjnego, paschalnego i pneumatologicznego.

\section{Wymiar inkarnacyjny}

Prawda o Chrystusie, Bogu-Człowieku, jest podstawą soteriologii, całego dzieła zbawczego. Przyjęcie przez Chrystusa ludzkiej natury spełnia, zdaniem Hryniewicza, decydującą rolę, ponieważ przez nie

\footnotetext{
2 Autor mówi o niej, że nie stanowi kolejnego traktatu teologicznego, ale jest „próbą spojrzenia na wiele zagadnień teologicznych w świetle wszechogarniającej tajemnicy Paschy Chrystusa"; Pascha I, s. 32. Choć Hryniewicz podejmuje temat misterium paschalnego z perspektywy historycznej, liturgicznej, biblijnej itp. to całość rozważań opiera się głównie na wymiarze konkretnym, osobowym i misteryjnym. Krótko mówiąc, unika języka abstrakcji i polemiki, a skupia się na osobie Jezusa Chrystusa oraz jego wydarzeniu zbawczym, wciąż obecnym w Kościele, dążąc do syntezy wielu ujęć i tradycji teologii paschalnej; por. tamże, s. 30. Sam wyjaśnia, że świadomie dążył, by język rozwijanej teologii w trzytomowym dziele nie miał tylko charakteru interpretacyjnego, ale by skłaniał do zadumy, doksologii, wyznania wiary i modlitwy; por. W. H r y $\mathrm{n}$ i e w i c z, Pascha Chrystusa $w$ dziejach czlowieka $i$ wszechświata. Zarys chrześcijańskiej teologii paschalnej, t. III, Lublin 1991, s. 17 (dalej: Pascha III). Warto też dodać, że trylogia paschalna jest owocem wieloletnich wykładów W. Hryniewicza na temat misterium paschalnego, rozpoczętych w 1966 r. w Katolickim Uniwersytecie Lubelskim. Jest próbą odpowiedzi na pytanie współczesnego człowieka o sens bycia chrześcijaninem, o istotę wiary chrześcijańskiej. Pierwszy tom, Chrystus nasza Pascha, skupia uwagę na jedności misterium paschalnego Chrystusa oraz sposobach jego interpretacji przez poszczególne tradycje: od Kościoła pierwotnego po czasy najnowsze. Tom drugi, Nasza Pascha z Chrystusem (W. H r yn i e w i c z, Nasza Pascha z Chrystusem. Zarys chrześcijańskiej teologii paschalnej, t. II, Lublin 1987; dalej: Pascha II) ukazuje Paschę Kościoła, która dokonuje się mocą wydarzeń zbawczych Chrystusa przez słowo i sakramenty. Tom trzeci, Pascha Chrystusa w dziejach człowieka $i$ wszechświata, stanowi zarys chrześcijańskiej antropologii i kosmologii paschalnej. Ukazuje Paschę człowieka, która dokonuje się w ciągu calego jego życia.
} 
została otwarta droga do udziału w życiu Stwórcy. Dzięki temu, że Chrystus stał się człowiekiem i zamieszkał pośród ludzkości oddalonej od Boga, stał się jednocześnie jej przedstawicielem wobec Niego. Jest to jednak dopiero początek udziału, ponieważ pełne uczestnictwo będzie możliwe przez zbawczą moc Paschy. Nowa więź solidarności Chrystusa z ludzkością, która zaistniała we wcieleniu, ujawni swą skuteczność dopiero w jej ostatecznym wypełnieniu. W samym akcie wcielenia, pisze autor trylogii paschalnej, zostaje nie tylko zamanifestowane pierwotne przeznaczenie do uczestnictwa w życiu Boga, ale z góry zamierzone i przyjęte kolejne wydarzenie zbawcze - śmierć i zmartwychwstanie. ${ }^{3}$

Hryniewicz bardzo mocno akcentuje integralność wydarzenia zbawczego. ${ }^{4}$ Zbyt jednostronne rozpatrywanie dzieła zbawczego jedynie przez pryzmat wcielenia, prowadzi, jego zdaniem, do tzw. soteriologii inkarnacjonistycznej. ${ }^{5}$ Problem ten zauważono pod koniec XIX w. głównie w gronie protestanckich badaczy doktryny chrześcijańskiej. Hryniewicz, przedstawiając wyniki ich badań, pisze, że według ich opinii, Ojcowie greccy nauczali, iż Chrystus w swoim wcieleniu przyjął kolektywnie całą ludzkość i tym samym dał wszystkim udział w swoim bóstwie. Zatem przebóstwienie ludzkości dokonałoby się bezpośrednio i automatycznie w samym akcie przyjęcia ludzkiej natury Chrystusa. ${ }^{6}$ Hryniewicz zdecydowanie przeciwstawia się

3 Śmierć na krzyżu i zmartwychwstanie jest dla Hryniewicza punktem wyjścia teologicznej refleksji. Podobnie rzecz ujmują W. Kasper i H. U. von Balthasar, dla których chrystologiczne rozważania rozpoczynają się od samoofiarowania się Syna Ojcu, a nie od Jego odwiecznego i czasowego narodzenia; zob. W. K a s p e r, Bóg Jezusa Chrystusa, tłum. J. T y r a w a, Wrocław 1966, s. 238; H. U.v o n B a I t h a s a r, Mysterium paschale, MySal 3/2, Einsiedeln 1969, s. 133-326. Kasper stwierdza, że celem wcielenia i całego wydarzenia Chrystusa jest właśnie krzyż, na które wszystko inne jest ostatecznie ukierunkowane. Podobnie twierdzi ks. Tadeusz Dola, gdy pisze o krzyżu jako celu i motywie wcielenia; zob. T. D o l a, Relacja krzyża do wcielenia, Studia Paradyjskie 8/1998, s. 191-202.

${ }^{4}$ Nie tylko Hryniewicz kladzie na to akcent. G. R. O' D ay, The Love of God Incarnate. The Life of Jesus in the Gospel of John, w: J. R. D o $\mathrm{n}$ a h u e (red.), Life in Abundance: Studies of John's Gospel in Tribute to Raymond E. Brown S. S., Collegevile 2005, s. 159-167, poświęca ten artykuł na omówienie integralności Jezusowej śmierci i życia. Uważa, że pod żadnym względem nie można tych dwóch kategorii pojmować separatystycznie. Jezus bowiem objawia Boga nie w autonomicznie rozumianym wydarzeniu śmierci, ale całym życiu.

5 Por. Pascha I, s. 136. Zdaniem Hryniewicza, nie można postrzegać wydarzenia zbawczego ani w ramach tzw. soteriologii inkarnacjonistycznej, ani przez pryzmat wąsko rozumianej soteriologii paschalnej. Jest jedno niepodzielne misterium zbawienia; zob. tamże, s. 138.

6 Hryniewicz wyjaśnia, że racje soteriologiczne skłoniły Ojców do akcentowania zbawczego znaczenia wydarzenia wcielenia. Nie znaczy to, że tworzyli soteriologię wyłącznie inkarnacjonistyczną. Ich soteriologia nie miała też charakteru wyłącznie paschalnego. Dla Ojców ła- 
temu stanowisku. W całej swojej trylogii wykazuje, że wcielenie nie ma ani autonomicznej, ani automatycznej mocy zbawczej. Chrystus we wcieleniu przyjmuje konkretną naturę ludzką, która dopiero przez swe wypełnienie w misterium paschalnym umożliwi ludzkości udział w Jego Bóstwie. Nie dokonuje się to automatycznie, ale wymaga dobrowolnego przyjęcia i aktywnej postawy człowieka. Dlatego, zdaniem Hryniewicza, należy rozpatrywać wcielenie w świetle całości dzieła odkupienia, które nadaje temu pierwszemu właściwe znaczenie. Trzeba w takim ujęciu wystrzegać się kreowania sztucznych opozycji. Nic nie dokonuje się autonomicznie. Sama bowiem Pascha konstatuje Hryniewicz - nie miałaby z kolei możliwości realizacji, gdyby nie teandryzm wcielenia. A ,jeśli istnieje soteriologia paschalna, to teandryzm wcielenia odgrywa w niej decydującą rolę jako ontologiczna podstawa wszystkich czynów Zbawiciela"?

Hryniewicz wyjaśnia, że wcielenie można rozumieć jako konkretny i jednostkowy akt, a jednocześnie jako permanentny stan zapoczątkowany tym wydarzeniem. By wytłumaczyć swoje stanowisko, odwołuje się do współczesnej antropologii, która proponuje dynamiczną interpretację natury ludzkiej. Twierdzi, że być człowiekiem, to znaczy stawać się nim ustawicznie. Pojmuje naturę ludzką jako nieustanny rozwój, stawanie się. To znaczy, że wolne akty, jakie człowiek podejmuje w całym swym życiu, mają charakter ontologiczny; sprawiają, że osoba ciągle urzeczywistnia się w swej istocie. W tej perspektywie wydarzenie wcielenia jawi się jako rzeczywistość, która rozciąga się na całe życie Jezusa. Hryniewicz nie podważa przez to niezmiennej istoty wcielenia, ${ }^{8}$ ale, poszukując ujęć pełniejszych, podkreśla jej dynamiczny i historyczny charakter, czyli wewnętrzne stawanie się i dopełnienie tajemnicy człowieczeństwa Chrystusa w całym Jego życiu, a zwłaszcza w szczytowym momencie - śmierci i zmartwychwstaniu. Dlatego pisze, że wcielenie nie zrealizowało się w betlejemskim żłóbku, ale w śmierci, zmartwychwstaniu i uwielbie-

cińskich wydarzenie paschalne było nieodłączne od osoby i życia Jezusa Chrystusa; por. tamże, s. 143.

7 Tamże. Wcielenie jako źródło i podstawa nie oznacza jednak sprawczego dzialania zbawczego, niezależnego od Paschy.

8 Por. tamże, s. 278-279. Hryniewicz thumaczy, że statyczna formula chrystologiczna Soboru Chalcedońskiego była podyktowana panującym ówcześnie błędnym rozumieniem jednej natury Chrystusa. Ten jednostronny aspekt, akcentujący wymiar ontologiczny wcielenia, wymaga jego zdaniem uzupełnienia bardziej dynamiczną koncepcją, którą proponuje tradycja aleksandryjsko-cyryliańska; por. tamże. s. 380 
niu Chrystusa. Inspirując się myślą wschodnią, podkreśla, że wcielenie nie jest statycznym przyjęciem natury ludzkiej, lecz nade wszystko wydarzeniem zbawczym. Stwierdza wprost: „Wcielenie to proces ontologicznej przemiany, która rozpoczyna się wcieleniem, a dopełnia się zwycięsko w zmartwychwstaniu". 9

Zdaniem Hryniewicza, paschalny dynamizm wcielenia uwidacznia się w całym życiu Jezusa. ${ }^{10}$ Już sam akt wyrzeczenia się chwały i uniżenia przez przyjęcie ciała wyraża kenozę Boga. Przyjęcie ludzkiego ciała implikuje bowiem przyjęcie śmierci, tak że wcielenie stanowi poniekąd „pierwszą stację drogi krzyżowej”." Także poszczególne wydarzenia z życia Jezusa są znakiem posłuszeństwa Ojcu i jako takie stanowią rzeczywistą cząstkę wydarzenia krzyża, ${ }^{12}$ jego antycypację. Dlatego od samego początku wszystko zmierza do wypełnienia w tajemnicy paschalnej. Wcielenie uzyskuje w niej ostateczne wypełnienie. Tym samym dopiero z perspektywy śmierci i zmartwychwstania można właściwie odczytać sens wcielenia i jego teologiczną wymowę.

Zdaniem lubelskiego dogmatyka, jeżeli nie uzna się jedności misterium paschalnego, tzn. dopełnienia tajemnicy wcielenia w misterium paschalnym, zwłaszcza w zmartwychwstaniu, wypaczy się znaczenie obydwu rzeczywistości, upatrując w nich dwie autonomiczne przyczynowości zbawcze. ${ }^{13}$ Tymczasem odkupienie nie dokonało się tylko we wcieleniu, ani tylko w Passze, lecz wtedy, gdy w pełni zostało zrealizowane wcielenie - czyli w uwielbieniu Chrystusa. Gdy-

9 Tamże, s. 279.

10 Zob. także ideę realizowania misterium paschalnego w codziennym życiu Jezusa w: J. M e y e n d o r f f, Christ's Humanity: The Paschal Mystery, St. Vladimir's Theological Quarterly 31/1987, s. 5-40.

"Pascha I, s. 280; zob. również zagadnienie ukierunkowania wcielenia i życia Jezusa ku krzyżowi w H. U. v on B a I t h a s a r, Teologia Misterium Paschalnego, tłum. E. P i o t r o w s k i, Kraków 2001, s. 10-13, 81-88.

12 Por. Pascha I, s. 279.

13 Zob. K. T a n n e r, Incarnation, Cross, and Sacrifice: A Feminist-Inspired Reappraisal, ATR 86/2004, s. 35-56. Zdaniem autorki, jedną z przyczyn niezrozumienia więzi, jakie istnieją między wcieleniem a śmiercią na krzyżu jest pojmowanie wcielenia w jego wąskim znaczeniu, tj. jako jednostkowego aktu odnoszącego się do narodzin Jezusa. Podobnie jak Hryniewicz, profesor z Uniwersytetu w Chicago zdecydowanie opowiada się za szerokim rozumieniem wcielenia, które obejmuje całe życie Jezusa. Autorka dodaje też, że zbawczych konsekwencji wcielenia nie można pojmować automatycznie, jakby mialy miejsce $w$ samym akcie przyjęcia ludzkiej natury Jezusa. W ten sposób moc zbawcza nie jest przypisywana ekskluzywnie ani wcieleniu, ani śmierci Jezusa, ale wydarzeniu, które obejmuje całe Jego życie, objawiające w różnoraki sposób obecność Boga; por. tamże, s. 7-14. 
by nie człowieczeństwo Chrystusa, Jego śmierć na krzyżu nie byłaby śmiercią w imieniu ludzkości i „dla naszego zbawienia”. Jednocześnie gdyby nie Jego Bóstwo oraz powstanie z martwych, wcielenie nie miałoby mocy zbawczej, nie przekraczałoby wieków i nie dosięgało każdego człowieka. „Nie zbawia - reasumuje lubelski teolog Bóg bez człowieka, ani człowiek bez Boga. Zbawia Bóg-Człowiek, Syn Boży, który „stał się człowiekiem dla naszego zbawienia”. ${ }^{14}$ Dlatego teandryzm wcielenia spełnia podstawową rolę $\mathrm{w}$ dziele zbawienia. Umożliwia człowiekowi udział w tym dziele. Nie dzieje się to jednak autonomicznie.

Zgłębiając myśl, autor trylogii paschalnej tłumaczy, że akt wcielenia jako pierwszy etap zbawienia, jest przyjęciem, a więc i przebóstwieniem konkretnego człowieczeństwa Chrystusa oraz przyjęciem konkretnego czasu, konkretnej historii. „We wcieleniu dokonało się zatem coś definitywnego. Jako przebóstwienie konkretnego człowieczeństwa Chrystusa jest już urzeczywistnieniem zbawienia. Natura ludzka została rzeczywiście, choć tylko w zaczątku, przebóstwiona za pośrednictwem jednej ze swoich osób. Od momentu wcielenia istnieje zatem w ludzkości ktoś całkowicie uświęcony, zdolny i gotowy do uświęcania i oczyszczania innych. Wszystko jest już dane, ale wszystko ma się jeszcze urzeczywistnić w cierpieniu, śmierci i zmartwychwstaniu Chrystusa". ${ }^{15}$ To zaczątkowe przebóstwienie indywidualnego człowieczeństwa, choć ma decydujące znaczenie jako źródło i podstawa zbawienia, nie ma autonomicznej mocy zbawczej niezależnej od zmartwychwstania. Wprawdzie dzięki jedności natury boskiej i ludzkiej Chrystus miał moc udzielania łaski i uczestnictwa w swym życiu, jednak pełny skutek zbawczy wcielenie osiągnęło dopiero w zmartwychwstaniu, gdy zostały usunięte wszelkie ograniczenia ludzkiej natury Jezusa.

Lubelski dogmatyk jest zdania, że człowieczeństwo Chrystusa nie zostało ukonstytuowane w swej funkcji odkupieńczej przez sam fakt osobowego zjednoczenia $\mathrm{z}$ bóstwem. ${ }^{16}$ Jest ono raczej drogą do zupełnie nowej rzeczywistości, która dokona się w zmartwychwstaniu, a którą autor określa mianem „nowe stworzenie”. „Początkiem tego «nowego stworzenia» jest nie natura ludzka Chrystusa w Jego egzystencjalnej sytuacji podobnej do naszej, lecz Jego człowieczeń-

\footnotetext{
14 Pascha I, s. 139.

5 Tamże, s. 143.

16 Por. tamże, s. 288.
} 
stwo przemienione i uwielbione w misterium zmartwychwstania (...). Wszystko, co poprzedziło tę przemianę było jedynie przygotowaniem do narodzin «nowego stworzenia» w Chrystusie zmartwychwstałym". ${ }^{17}$ Jezus musiał w swym człowieczeństwie najpierw sam przejść tę przemianę, by dzięki niej stać się źródłem przemiany dla innych. Jego solidarność z ludźmi, oparta na wspólnocie natury, dopiero tutaj osiągnęła pełną moc zbawczą. Dopiero w Chrystusie zmartwychwstałym Jego wcielenie rozciągnęło się na całą ludzkość, w wyniku czego poszczególny człowiek może stać się uczestnikiem zbawienia. Oczywiście, nie dzieje się to automatycznie, lecz dzięki chwalebnemu człowieczeństwu Chrystusa, mocą Ducha, przez wiarę i sakramenty. ${ }^{18}$ Wcielenie jednak umożliwiło, a dzięki zbawczej mocy Paschy sprawiło, że historia i to, co ludzkie, staje się życiem osobowego Boga.

Jedność wydarzenia zbawczego, Hryniewicz ilustruje, odnosząc się do struktury zdania. ${ }^{19}$ Choć składa się ono z wielu słów, mających autonomiczne znaczenie, dopiero w całości, gdy zostanie wypowiedziane ostatnie słowo, wyraża zamierzoną przez autora treść. Czymś analogicznym, choć nieskończenie wyższym, jest dzieło zbawcze Słowa Wcielonego. W jego jedności zawarte są poszczególne momenty: życie, śmierć, zmartwychwstanie, a jednocześnie w każdym $\mathrm{z}$ nich obecne już jest całe misterium zbawienia.

Innym przykładem, którym posługuje się lubelski dogmatyk w celu zobrazowania jedności całego dzieła zbawienia jest spirala. ${ }^{20}$ Początkiem i czynnikiem nadającym spirali wewnętrzną jedność jest wcielenie. Rozwija się ono w ciągu całego życia Jezusa, a swoją wewnętrzną istotę i cel ukazuje w zmartwychwstaniu, które jest odsłonięciem i wypełnieniem tego, co już zaistniało we wcieleniu.

W tym sensie, autor trylogii paschalnej tłumaczy, można mówić o wcieleniu, jako wydarzeniu zbawczym, pod warunkiem że pojmuje się je jako w pełni zrealizowane w śmierci i zmartwychwstaniu Chrystusa. Dopiero wówczas, w ramach takiego dynamicznego ujęcia, można stwierdzić, że wcielenie jest przyjęciem nie tylko jednostkowego człowieczeństwa, lecz także całej historii ludzkości i świata.

17 Tamże.

18 Por. tamże, s. 137.

19 Por. tamże, s. 379-380. Autor zaczerpnąl to porównanie od Ch. J o u r n e t, L'Eglise du Verbe Incarné, t. II, Bruges 1951, s. 171.

211 Por. Pascha I, s. 379. 


\section{Wymiar paschalny}

Jedną z podstawowych prawd wiary chrześcijańskiej jest wyznanie, że Chrystus ,dla nas ludzi i dla naszego zbawienia zstąpił z nieba (...), stał się człowiekiem. Ukrzyżowany również za nas, pod Poncjuszem Piłatem został umęczony i pogrzebany". Formułą hyper hemon, która oznacza: „na naszym miejscu”, „zamiast nas”, „w naszym imieniu", ,jako przedstawiciel nas wszystkich", często posługuje się Nowy Testament, by wyrazić głęboką więź, jaka istnieje między Chrystusem a ludzkością. ${ }^{21}$ Hryniewicz jest przekonany, że motyw zastępstwa, jeden z najstarszych elementów wyznania wiary chrześcijańskiej, ma swoją podstawę w idei solidarności, nie zaś w jurydycznie zabarwionej idei zadośćuczynienia. Idea solidarności Chrystusa z ludzkością, która ma swój początek w tajemnicy wcielenia, w pełni ujawnia swój skutek zbawczy w śmierci i zmartwychwstaniu. To znaczy, że sens formuły „dla nas” wyjaśnia się dopiero w jedności misterium paschalnego, a zwłaszcza w świetle nowej egzystencji Zmartwychwstałego, która ukazuje definitywnie, że wszystko, co Chrystus przeżył i uczynił, dokonało się i dokonuje nadal w imieniu i dla dobra całej ludzkości. ${ }^{22}$

\section{Zbawczy sens śmierci Jezusa}

Sposób zbawienia, jaki Bóg wybrał, przekracza ludzkie możliwości zrozumienia. Pełna cierpienia i hańby śmierć staje się bramą zmartwychwstania dla wszystkich ludzi. Lubelski teolog przyznaje w sposób właściwy jego apofatycznej wrażliwości, że tego Bożego wyboru nie da się uzasadnić. Nie jest też łatwo teologicznie wyjaśnić zbawczy sens śmierci Jezusa oraz jej wpływ na człowieka. Stanowi ona tajemnicę wolności i miłości Boga, który w ten właśnie boski sposób pragnie pozyskać ludzką wolność. Krzyż, zdaniem Hryniewicza, jest przede wszystkim osobowym darem Boga, który zapra-

${ }^{21}$ Por. tamże, s. 444. Hryniewicz lansuje tutaj ideę zastępstwa, ale formułę hyper hemon, pro nobis częściej tłumaczy się jako „za nas”, „za wielu”, „dla nas”; zob. H. U. v o n B a l t h a$\mathrm{s}$ a r, Crucifixus etiam pro nobis, thum. L. B a $1 \mathrm{t}$ e r, ComP 19(1984) nr 1, s. 18-28.

${ }_{22}$ W. K a s p e r wyraża przekonanie, że nie można mówić o Bogu w sobie samym, z pominięciem człowieka, lecz tylko o Bogu „dla mnie i dla nas”, o Bogu w relacji do człowieka; por. t e n ż e, Bóg Jezusa Chrystusa, s. 88. 
sza każdego człowieka do współuczestnictwa w tym dziele i oczekuje jego odpowiedzi. ${ }^{23}$

Ekumenista nie zgadza się z taką koncepcją śmierci, która ukazuje ją jako zadośćuczynienie zagniewanemu Ojcu, w wyniku czego zmienia On swą postawę i przebacza człowiekowi winę. Jego zdaniem, w ciągu wieków posługiwano się wieloma różnymi kategoriami i obrazami próbującymi przybliżyć sens misterium śmierci Jezusa, np. wykup, zasługa, zadośćuczynienie. ${ }^{24}$ Kategorie te powstawały w danym kontekście historycznym i były nasiąknięte sposobem myślenia danej epoki. Analogicznie dziś, uwzględniając obecne uwarunkowania, należy przybliżać zbawczy sens śmierci w kategoriach bardziej personalistycznych i integralnych. ${ }^{25}$

Krzyż jest, zdaniem Hryniewicza, ostateczną odpowiedzią Chrystusa na inicjatywę Ojca, który posłał Syna, ,aby dał swoje życie dla zbawienia świata". To oddanie - thumaczy - nie było aktem karzącej

${ }^{23}$ Por. Pascha I, s. 411-412, 428. Podobną myśl można odczytać w Z. K i j a s, Tajemnica krzyża w teologii H. Urs von Balthasara i S. Fłoreńskiego, w: t e n ż e (red.), Teologia krzyża w ujęciu ekumenicznym. Materiały z sympozjum, Kraków 1994. Według pierwszego teologa, krzyż jest zmaterializowaną formą Bożej miłości, pragnącej pozyskać człowieka. Dla drugiego zaś, krzyż powinien stanowić formę odpowiedzi człowieka na Bożą miłość; zob. tamże, s. 87.

${ }^{24}$ Por. Pascha I, s. 384, 392-396; teorie te zbierają i opisują J. C a r l s o n B r o w n, R. P a r k e r, For God So Loved the World? w: Christianity, Patriarchy and Abuse: A Feminist Critique, Cleveland 1989, s. 1-30. Klasyczną tradycję wyjaśniającą sens śmierci Jezusa, czyli teorię zadośćuczynienia, rozpatrują przez pryzmat trzech innych teorii: 1 . t e o r i a o k u$\mathrm{p}$ u: Chrystus ukazywany jest jako Zwycięzca, który uiścił należność szatanowi; 2 . $\mathrm{t}$ e o $\mathrm{r}$ i a $\mathrm{s}$ a t y s f a k c j i lub z a s t ę p s t w a (Anzelm z Canterbury, Cur Deus homo?), według której Jezus, jako ofiara zastępcza, zajął miejsce człowieka, aby usatysfakcjonować Boży gniew wskutek popełnionych grzechów. Tylko ktoś, kto jest równy Bogu mógł udzielić rekompensaty; 3. t e or i a m o r a l n e g o w pły w u (Piotr Abelard), wedlug której śmierć Jezusa miała na celu przekonać ludzi do ogromu łaski Bożej i w ten sposób przyczynić się do ich nawrócenia przez obudzenie w ludziach wdzięczności [tłum. własne]. Te trzy teorie ukazują śmierć Jezusa jako zaplanowaną i pożądaną przez Boga dla wyzwolenia ludzkości od grzechów. Pierwsza zdaje się skierowana do szatana, druga wyraźnie do obrażonego Boga, a trzecia do ludzkości. Dopiero w XX w. pojawily się kierunki krytykujące teorie zadośćuczynienia. Należą do nich m.in. teorie mówiące o Bogu współcierpiącym z ludzkością i akcentujące cierpienie jako konieczną część historycznego procesu walki o wyzwolenie. Zob. także precyzyjnie omówione przez $\mathrm{Cz}$. Bartnika teorie soteriologiczne: 1. teorie wewnątrzbiblijne; 2 . teorie niewoli diabelskiej; 3 . teorie ekonomio-zbawcze; 4. teoria zadośćuczynienia; 5. teoria zasługi; 6. teoria substytucji karnej; 7. teoria miłości soteriologicznej; 8. teoria mistycznej kenozy Bożej; 9. teoria eudajmonistyczna; 10. teoria wyzwolenia; 11. teoria omegalizacji persono-genetycznej, w: Cz. B a r t n i k, Dogmatyka katolicka, t. I, Lublin 2000, s. 724-729.

${ }^{25}$ Integralność ta obejmuje nie tylko jedność poszczególnych momentów dziela zbawczego, ale także komplementarność modeli soteriologicznych: zstępującego i wstępującego. Zdaniem Hryniewicza, takie ujęcie pozwoli uniknąć soteriologicznych skrajności; por. Pascha I, s. 391 . 
sprawiedliwości, ale miłości, która ma swe źródło w wewnętrznym życiu Trójcy Świętej. ${ }^{26}$ Forma ofiary krzyżowej jest najpierw wyrazem wiecznego oddania Syna wobec Ojca. Następnie, w konsekwencji przyjętego człowieczeństwa, jest czynem wyrażającym całożyciowe Jego nastawienie i w niej mają spełnienie wszystkie czynności wykonywane za życia. Hryniewicz nawiązuje do intuicji współczesnych teologów, którzy pojmują śmierć jako wydarzenie wielowarstwowe, będące jednocześnie „osobowym czynem człowieka oraz jego biernym oddaniem na znak absolutnego posłuszeństwa względem Boga; opuszczeniem postaci cielesnej i wejściem ducha ludzkiego w nowy, wszechogarniający stosunek do rzeczywistości; kresem trwania historycznego i dopełnieniem osobowego życia od wewnątrz". ${ }^{27}$ Ponieważ Chrystus w akcie wcielenia przyjął ludzką naturę, także Jego śmierć w swojej wewnętrznej strukturze, w swym stanie ciemności i niemocy, była podobna do śmierci ludzkiej. Nie była ona jednak jedynie biernym doznaniem, lecz czynem, w którym skoncentrowało się całe Jego życie, całe oddanie Ojcu w ciągu ziemskiego życia. I ten właśnie wewnętrzny wymiar śmierci został nadany jej przez samego Chrystusa, dzięki czemu nie zło, ale siła oddania, miłości, posłuszeństwa staje się najbardziej doskonałą drogą do zjednoczenia z Bogiem.

Autor trylogii paschalnej wyjaśnia, że krzyż, cierpienie i śmierć są w istocie złem, następstwem grzechu i same w sobie nie mają mocy zbawczej. W wydarzeniu Chrystusa stają się jednak formą, zewnętrznym czynnikiem do wyrażenia Chrystusowej miłości i oddania względem Ojca i ludzi. ${ }^{28} \mathrm{~W}$ tym przeżyciu zewnętrznej formy, najpełniej

${ }^{26}$ Hryniewicz nie rozwija refleksji nad wewnętrznym życiem Trójcy. Stwierdza krótko, że przyczyną przyjścia Chrystusa na świat była konieczność oddania się Ojcu w formie ofiary, ponieważ tylko taki sposób jest w stanie wyrazić Jego wieczne oddanie. „W wewnętrznym życiu Trójcy Świętej oddanie się Syna Ojcu nie może być w tym samym stopniu rezygnacją i ofiarą"; tamże, s. 437. Na temat odkupieńczej ofiary Chrystusa jako wypełnienia Bożego planu miłości zob. także w: J a n P a w e ł II, Wierzę w Jezusa Chrystusa Odkupiciela, Watykan 1989, s. 289-293.

27 Hryniewicz czerpie te refleksje od Karla Rahnera; zob. Pascha I, s. 431.

${ }^{28}$ Hryniewicz stwierdza, że zło krzyża ma wartość funkcjonalną, staje się drogą do urzeczywistnienia dobra; por. tamże, s. 412, 434. R. B i e r i n g e r, w artykule Jesus' Death as a Crime committed by Humans (w przyg. do druku) wyraża mocne przekonanie, że krzyż nie był żadną miarą zaplanowany przez Boga, ale był przestępstwem dokonanym przez ludzi wskutek zawiści wobec dobra, które czynił Jezus. Niemiecki biblista uważa, że Jezus wcale nie musiał umierać na krzyżu, ale równie dobrze mógl umrzeć jako starzec. Tym, co ma moc zbawczą, jest całe jego życie, głoszenie Dobrej Nowiny o Bogu i uzdrawianie ludzi z wszelkich rodzajów zła. Ta właśnie dzialalność stała się przeszkodą dla tych, którzy czerpali korzyść z wszelkich sytuacji niesprawiedliwości i jako taka, stała się przyczyną śmierci Jezusa. Bóg jednak w wydarzeniu zmartwychwstania nie pozwolił ostatecznie, by ludzie udaremnili Jego plan zbawie- 
wyraża się, zdaniem Hryniewicza, ludzkie współdziałanie Chrystusa w dziele zbawienia oraz najwyższa realizacja stosunku człowieka do Boga, która odtąd ma się stać miarą doskonałej relacji. W ten sposób, doświadczając w ludzkiej śmierci oddania Bogu, Chrystus przezwycięża siłę jej zła i grzechu. Zbawia nie krzyż sam w sobie, ale miłość. I okazuje się, że ostatnie słowo nie należy do śmierci. Milczenie zawarte w dramacie krzyża stało się przejściem, drogą do doskonalszego, pełnego zjednoczenia z Bogiem, który w zmartwychwstaniu Chrystusa daje boską odpowiedź na Jego oddanie: miłość za miłość. ${ }^{29}$

Usiłując lepiej wyrazić zbawczy sens śmierci krzyżowej Chrystusa dla nas, Hryniewicz przybliża jej treść w kategorii ofiary paschalnej. Thumaczy, że kategoria ta nie ma w sobie nic z porządku karnego. ${ }^{30}$ Jest ofiarą, ponieważ urzeczywistnia w pełni cel wszystkich poprzedzających ją ofiar: zjednoczenie z Bogiem, pojednanie i prze-

nia. Bieringer stwierdza jednak, że śmierć Jezusa nie była na próżno. Nie zbawia śmierć sama w sobie, ale miłość i wierność Jezusa, która została wyrażona w tej formie.

${ }_{29}$ Por. Pascha I, s. 432. Wiele tego rodzaju przemyśleń Hryniewicz czerpie z refleksji Edwarda S c h i ll e b e e c k x a; zob. t e n ż e, Chrystus, sakrament spotkania z Bogiem, thum. A. Z u b e r b i e r, Kraków 1966, s. 44.

${ }^{30} \mathrm{~W}$ trylogii, z lat 1982-1991, W. H r y n i e w i c z posługuje się swobodnie kategorią ofiary paschalnej. Zastrzega jednak, że nie chodzi mu $w$ niej o jurydystyczne rozumienie ofiary jako zadośćuczynienia. Natomiast $w$ artykule z 2001 r., t e $n$ ż e, Czy Bogu potrzebne sq ofiary? Pytania o przyszłość chrześcijaństwa, TPow 55(2001) nr 2, s. 8-9, sugeruje rezygnację z terminu „ofiara”. Kierując się troską o przyszłość wiary uważa, że ta terminologia doprowadziła w historii chrześcijaństwa do wielu wypaczeń i w konsekwencji wyrządziła wiele krzywd oraz odstępstw od wiary. Jego zdaniem, także w obecnych czasach termin „ofiara” ma negatywne konotacje i przez niebezpieczny potencjał prowadzi do niezrozumienia właściwego sensu zbawczej śmierci Jezusa. Dlatego lubelski teolog proponuje zamianę tego terminu na słowo „dar” bądź koryguje nazwę przez stosowanie terminologii: „dar paschalnej ofiary”; zob. szerzej: t e n ż e, Żyjemy z daru paschalnej ofiary, w: S. K o p e r e k, J. S z c z e p a n i a k, W. Z u z a k (red.), Eucharystia na ottarzu świata, t. IV, Kraków 2006, s. 49-69. Zob. także szeroką dyskusję wywołaną artykułem Hryniewicza: J. K r a c i k, Jego ofiarq obdarowani, TPow 55(2001) nr 9, s. 11; Z. K u b a ck i, Bóg ofiary ekspiacyjnej czy egzystencjalnej? Wokót teologii ofiary Chrystusa, SThV 39(2001) nr 1, s. 35-70; H. W i t c z y k, Pascha Jezusa odpowiedziq Boga na grzech świata. Eschatologiczna ofiara ekspiacji i Nowego Przymierza, Lublin 2003; t e n ż e, Smierć i zmartwychwstanie Jezusa jako ofiara nowej paschy, Liturgia sacra 8(2002) nr 2, s. 21-224; zob. także R. J. D a i 1 y, The Origins of the Christian Doctrine of Sacrifice, Philadelphia, 1978; Ch. A. E b e r h a r t, The Term ,, Sacrifice” and the Problem of Theological Abstraction: A Study of the Reception History of Genesis 22: 1-19, w: Ch. H e I m e r, Ch. T. H i g b e (red.), The Multivalence of Biblical Text and Theological Meanings, Atlanta 2006, s. 47-66; Ch. A. E b e rh a r t, Characteristics of Sacrificial Metaphors In Hebrews, w: G. G e I a r d i n i (red.), Contemporary Methods - New Insights, Leiden-Boston 2005, s. 37-64. 
miana człowieka. ${ }^{31}$ Starotestamentalne ofiary nie były w stanie doprowadzić do pełnego zjednoczenia z Bogiem. Dopiero Jezus, nadając swojej śmierci charakter ofiary pojednania, ofiary ze swojego życia za wszystkich ludzi, przywraca przymierze z Bogiem, ponieważ Jego dar zostaje całkowicie przyjęty przez Boga. Dzięki odkupieńczemu charakterowi tej ofiary, „dobrowolnie przyjęta przez Jezusa śmierć nie była ofiarą pojedynczego człowieka, który dążył do pełni osobistego zjednoczenia z Bogiem. Była to śmierć mesjańska, śmierć w imieniu i dla dobra ludzi. To była ofiara Najwyższego Kapłana umierającego w zastępstwie i dla dobra całej ludzkości, sprawującego w sobie odkupieńczy kult Boga, do którego nie byli zdolni" ${ }^{32}$ Dlatego śmierć Chrystusa stała się największą służbą kapłańską jakiej kiedykolwiek dokonano w ludzkich dziejach. Dzięki niej zaistniała możliwość, by przez kolejne wieki każdy człowiek mógł dobrowolnie uczestniczyć w kapłańskim posługiwaniu Chrystusa. On bowiem został złożony w ofierze jako nasza Pascha (por. 1Kor 5,7) i dlatego „w ofierze paschalnej bierze swój początek powszechne kapłaństwo wszystkich wierzących". ${ }^{33}$ Ofiara ta dokonana przez Jezusa, Syna Bożego oznacza, że zbawienie jest i na zawsze pozostanie darem Boga. Jednocześnie jako czyn Jezusa, Syna Maryi, ujawnia, że zbawienie wymaga ludzkiej aktywności. Chodzi o uczestnictwo w doskonałym kulcie Chrystusa. Dzięki Niemu prototypicznie dokonana rzeczywistość zbawienia rodzaju ludzkiego stale się urzeczywistnia w ludzkiej egzystencji. ${ }^{34}$

Hryniewicz wyjaśnia, że przyjęcie przez Boga ofiary należy w sposób konieczny do jej istoty i warunkuje jej skuteczność. Złożenie Bogu daru swojego życia i przyjęcie go przez Boga, które powoduje jego uświęcenie i przemienienie, stanowią dwa etapy jednego wydarzenia, których nie można od siebie oddzielać. W ten sposób Hryniewicz tłumaczy, że zbawczy sens śmierci Chrystusa ukazuje się dopiero $\mathrm{w}$ zmartwychwstaniu, które nie jest zewnętrzną manifestacją, ale jej wewnętrznym następstwem. ${ }^{35}$ Uważa, że choć istniało następ-

31 Por. Pascha I, s. 434. Innymi słowy, wyraża całkowity dar z życia. By wypowiedzieć się jeszcze precyzyjniej, Hryniewicz wyjaśnia, że ofiara jest zwróceniem Dawcy daru, który się wcześniej otrzymało. Nie oznacza więc danie Bogu czegoś, ale uznanie Go za Stwórcę i Pana wszystkiego.

32 Tamże, s. 446.

33 Pascha II, s. 80.

34 Por. Pascha I, s. 440-441.

35 Por. tamże, s. 432-438. 
stwo czasowe między tymi wydarzeniami, śmierć Chrystusa zawierała w sobie zmartwychwstanie jako jej istotne dopełnienie. Lubelski dogmatyk wielekroć podkreśla, że śmierć i zmartwychwstanie nie stanowią oddzielnych od siebie aktów zbawczych, ale wewnętrzne przejście od jednej fazy do drugiej. W swej istotnej strukturze zbawczej kształtują nierozerwalną jedność i nie można właściwie zrozumieć sensu tajemnicy paschalnej oraz jej znaczenia dla człowieka, rozpatrując je w oderwaniu od siebie. Krzyż nie ma mocy zbawczej autonomicznie. Śmierć, wyjaśnia lubelski teolog, ma sens jedynie jako przejście do zmartwychwstania, które jest uwieńczeniem ofiary i przyjęciem jej przez Ojca. Gdyby nie zmartwychwstanie, Jego śmierć nie miałaby charakteru odkupieńczego, nie byłaby śmiercią mesjańską, śmiercią dla nas. Zmartwychwstanie jest zatem kulminacyjnym aktem i uwieńczeniem całego dzieła odkupienia zapoczątkowanego przez wcielenie i dokonanego przez krzyż. ${ }^{36}$

\section{Zmartwychwstanie jako obecność Żyjącego}

Nie można postrzegać zmartwychwstania jako dodatkowego aktu zbawczego. Stanowiło ono istotne dopełnienie ofiary Chrystusa, dzięki czemu cały Jego czyn, zapoczątkowany we wcieleniu, stał się zwycięstwem nad śmiercią. Jednocześnie zmartwychwstanie stało się początkiem czegoś nowego. Zapoczątkowało nowy sposób istnienia Chrystusa dla świata i odmieniło jego historię. Jego człowieczeństwo nie podlega już więcej ograniczeniom przestrzenno-czasowym. Hryniewicz stwierdza: „Bóg wprowadziwszy człowieczeństwo Jezusa w przestrzeń swojej boskiej egzystencji, uwielbił je i uczynił powszechnym "sakramentem zbawienia»". ${ }^{37}$ To znaczy, że przemiana, jaka się dokonała w zmartwychwstaniu, polegała nie tylko na osobistym uwielbieniu Jezusa, lecz w Nim, solidarnie zespolonym z ludzkością, stała się także w nadziei udziałem wszystkich ludzi. ${ }^{38}$

36 Por. tamże, s. 440 .

37 Tamże, s. 381.

38 Antropologicznym implikacjom zmartwychwstania $\mathrm{H}$ r y n i e w i c z poświęca wiele uwagi w swym innym dziele, omawiając ideę bogoczlowieczeństwa. Choć w trylogii kilkakrotnie posługuje się tym sformułowaniem, nie omawia tak wyraźnie jego następstw, jak w: t e nż e, Bóg naszej nadziei. Lublin 1989. Jego zdaniem, doniosłość idei bogoczłowieczeństwa polega na tym, że „wyrosla ona z szeregu prób interpretacji wzajemnego stosunku tego, co Boskie i ludzkie w Chrystusie, w czlowieku, w misterium Kościola, w kulturze i w calych dziejach ludzkości"; tamże, s. 166. Niweluje wszelkie paradoksy oraz przeciwstawia się wszelkim skrajnościom: przezwycięża zbyt manicheizujący transcendentyzm antropologiczny jak i czysto hu- 
Zmartwychwstanie w ujęciu Hryniewicza, to „tajemnica tajemnic", ${ }^{39}$ której nigdy nie wyczerpie się ludzkim językiem i której nie sposób rozważać bez wiary. Jako wydarzenie jednorazowe, nie ma w dziejach ludzkości żadnego odpowiednika. Nikt nie był jego świadkiem i sam akt pozostaje nie znany. Jest jednak wydarzeniem rzeczywistym, choć należącym do nowego porządku eschatycznego. ${ }^{40}$ Jako takie ,jest wielkim i niepojętym przełomem w dziejach świata, przekroczeniem granic historii, wypełnieniem czasu, wejściem w nowe życie przyszłego wieku". ${ }^{41}$ Jest wydarzeniem metahistorycznym i transcendentnym, a jednocześnie rzeczywiście styka się z dziejami ludzkimi i pozostawia w nich ślad, którego znakiem jest pusty grób i chrystofanie. One świadczą o wielkiej przemianie, która się dokonała, a której skutkiem jest trwała i głęboka obecność Zmartwychwstałego w świecie, mimo Jego odejścia. ${ }^{42}$ Jest to odtąd obecność wewnętrzna, której Hryniewicz nie waha się nazwać eklezjalną i misteryjną. Tłumaczy, że Chrystus zmartwychwstał po to, by jeszcze głębiej wejść w ludzkie dzieje, dzieje Kościoła. ${ }^{43}$ Dzięki temu może spontanicznie się udzielać, inicjować spotkanie z ludźmi wszystkich czasów, nawet wtedy, gdy Go nie rozpoznają. Przy tym lubelski ekumenista od razu zaznacza, że nie chodzi o rozpoznanie wizualne, ale

manistyczny immanentyzm; implikuje wzajemną otwartość na siebie zarówno u człowieka jak i u Boga, prowadząc do wzajemnej koegzystencji rzeczywistości ludzkiej w Bogu oraz Boskiej w człowieku; niweluje alternatywę horyzontalizmu i wertykalizmu - człowiek jest powołany nie tylko do troski o swe zbawienie, ale także do twórczości i zaangażowania w proces kultury i przetwarzania świata; ,wyklucza dualizm Kościoła i świata, Kościoła i kultury, sakralnego i świeckiego, wertykalnego i horyzontalnego, zbawienia i twórczości (...) Hryniewicz konstatuje również, że bogoczłowieczeństwo nie jest dziełem samej wszechmocy Bożej, lecz również wynikiem ludzkiego wspóldziałania. Dlatego wymaga zachowania elementu Boskiego z równoczesnym powiązaniem aktywnego elementu ludzkiego. „Chrześcijaństwo nie jest religią czysto horyzontalnego etosu «współczłowieczeństwa». Z drugiej strony nie jest również religią wertykalnego solus Deus. Jest religią harmonijnej syntezy Boskiego i ludzkiego - religią bogoczłwoieczeństwa, naświetlająca Boskie wymiary człowieka, jego twórczości i całego kosmosu"; tamże, s. 172. Podobne stwierdzenia, choć nie tak wyraźnie sformułowane, można znaleźć w trylogii paschalnej tam, gdzie autor mówi o implikacjach chwalebnego człowieczeństwa Chrystusa; por. Pascha III, s. 118, 212-213.

${ }_{39}$ Por. Pascha I, s. 261; W. H r y n i e w i c z, Tajemnica Chrystusa w teologii prawostawnej i protestanckiej, s. 432.

40) Por. Ch. S c h ö n b o r n, Bóg zestat Syna swego. Chrystologia, tłum. L. B a l t e r, Poznań 2002, s. 345-350.

${ }^{41}$ Pascha I, s. 324.

42 Autor refleksji paschalnych przypomina, że Chrystus żegnając się z uczniami wypowiada słowa: „Oto ja jestem z wami po wszystkie dni” (Mt 28, 20); por. Pascha I, s. 337.

43 Por. tamże, s. 338. 
wewnętrzne, dokonujące się w głębi jestestwa człowieka, w osobowej relacji, co bynajmniej nie odbiera temu spotkaniu ontologicznego znaczenia. Wątek ten zostanie rozszerzony w następnym rozdziale.

Odczytując teologiczny sens ukazywania się Zmartwychwstałego, Hryniewicz wyjaśnia, że głównym celem chrystofanii jest powołanie wspólnoty Kościoła do określonego zadania. Chodzi o przedłużenie misji samego Chrystusa i uobecnianie Jego osoby w każdym czasie i każdym miejscu po to, by wszystkich doprowadzić do wspólnoty z sobą. Dlatego „odejście Chrystusa nie czyni z ziemi jedynie padołu łez ani miejsca przejściowego pobytu i tęsknoty za wiecznością". ${ }^{44}$ Zdaniem autora, odejście Chrystusa każe z jeszcze większą aktywnością świadczyć o Zmartwychwstałym. Wraz z ostatnią chrystofanią, zakończoną wniebowstąpieniem, rozpoczyna się epoka, w której obecność Chrystusa trzeba odnajdywać w ludziach, w ich słowie i działaniu. ${ }^{45} \mathrm{~W}$ nich rozpoznanie Zmartwychwstałego dokonuje się nie inaczej, jak dzięki Duchowi przez wspólnotę słowa i posiłku. Zmartwychwstały, choć w sposób ukryty, pozostaje rzeczywiście z ludźmi. To znaczy, że „odkupienie jest nieustanną bliskością Tego, który odszedł". ${ }^{46}$ Odszedł po to, by jeszcze bliżej być.

W ten sposób Hryniewicz wyjaśnia, że zmartwychwstanie nie pozostaje bez wpływu na ludzkie dzieje, ale przenika je jeszcze głębiej. Od momentu uwielbienia ciało Zmartwychwstałego, zachowując ciągłość z ciałem historycznym, nie jest już tylko ciałem indywidualnym, ale staje się „ciałem eklezjalnym”, ogarniającym cały wszechświat. Przeniknięte działaniem Ducha Świętego ciało Chrystusa jest jednocześnie osobowe i kolektywne. Cytując słowa X. Leon-Dufoura, stwierdza, że „Jezus Chrystus jest równocześnie osobą, która przyjmuje wszechświat oraz wszechświatem w Nim uosobionym". ${ }^{47}$ Ta tajemnicza więź sprawia, że ludzkość i wszechświat otrzymuje już teraz udział w chwale Zmartwychwstałego. Hryniewicz wyjaśnia, że zmartwychwstanie, choć wyniosło Chrystusa ponad kosmos, nie przekreśliło Jego związków ze światem. Przeciwnie, od tego momentu, świat i ludzkość zostały nierozerwalnie związane z Nim jako Panem całego

44 Tamże, s. 344.

45 Por. tamże, s. 343-344.

46 Jest to stwierdzenie jakie Hryniewicz zaczerpnął od S. A. G r u d a [K. Wojtyła], Odkupienie szuka twego ksztattu, by wejść w niepokój wszystkich ludzi, Znak 31(1979) nr 304, s. 975-979, s. 978; cyt. za: Pascha I, s. 454.

47 Tamíe, s. 355. 
stworzenia. Zmartwychwstanie sprawia, że duchowe ciało Chrystusa udziela się odtąd całemu stworzeniu w akcie mającym w sobie podobieństwo do przemiany eucharystycznej i tak staje się ,eucharystią" dla całego świata. ${ }^{48}$ Tak Bóg realizuje zamierzoną w stworzeniu pierwotną sakramentalność świata. Przez nowe stworzenie dokonuje dzieła rekapitulacji świata. Chrystus jest w swym ciele pierwszym przemienionym, który wprowadza ludzkość w zupełnie nowy rodzaj egzystencji. Wspólnota z Chrystusem jest już rzeczywistością zbawczą. Dlatego można mówić o Nim, że jest powszechnym sakramentem zbawienia. ${ }^{49}$

Powyższa myśl każe Hryniewiczowi spojrzeć na wydarzenie zmartwychwstania z jeszcze innej strony. Zauważa, że zbawcze znaczenie misterium paschalnego nie wyczerpuje się w osobistym uwielbieniu Chrystusa i uzasadnieniu chrześcijańskiej wiary. Przemiana, dokonana w zmartwychwstaniu, sprawiła nie tylko nową obecność Chrystusa w świecie, ale jednocześnie wprowadziła ludzkość w przestrzeń samego Boga. Przez zmartwychwstanie i wniebowstąpienie Chrystus wraz ze swą ludzką naturą wszedł w krąg Bożych osób, ${ }^{50}$ a wraz z Nim ci, którzy na przestrzeni kolejnych wieków będą się z Nim jednoczyć. Dzięki temu ,dokonało się coś nieodwracalnego: nic nie zdoła już oddzielić natury ludzkiej od natury Bożej. Przez ten fakt właśnie cała ludzkość została potencjalnie zbawiona; chodzi już tylko o dobrowolne przyjęcie przez poszczególnych ludzi tego, co zostało osiągnięte dla całej natury ludzkiej". ${ }^{51}$

48 Por. tamże, s. 356. Szerzej na temat kosmicznego zasięgu tajemnicy paschalnej zobacz W. H r y n i e w i c z, Staroruska teologia paschalna w świetle pism św. Cyryla Turowskiego, Warszawa 1993, s. 121-123.

49 Por. Pascha I, s. 398; Pascha II, s. 215-218.

s0 Myśl tę rozwija też Benedykt XVI w swojej homilii na uroczystość Wniebowstąpienia Pańskiego. Papież stwierdza: „On [Chrystus] - odwieczny Syn - doprowadził nasze człowieczeństwo przed oblicze Boga, poniósł z sobą w przemienionej postaci ciało i krew. Człowiek znajduje swoją przestrzeń w Bogu; przez Chrystusa istota ludzka została wprowadzona w życie samego Boga. Ponieważ zaś Bóg ogarnia i podtrzymuje cały wszechświat, Wniebowstąpienie Chrystusa oznacza, że On nie oddalił się od nas, ale że dzięki swojemu byciu z Ojcem jest teraz blisko każdego z nas, na zawsze"; Posługa Papieża gwarancja postuszeństwa Chrystusowi i Jego słowu. Msza św. w bazylice św. Jana na Lateranie z okazji objęcia katedry biskupa Rzymu (07.05.2005), OsRomPol 26(2005) nr 7-8, s. 19.

51 Pascha I, s. 76. Tę samą myśl można znaleźć w innym miejscu trylogii paschalnej, gdy Hryniewicz prezentuje antropologiczne wymiary zmartwychwstania naszkicowane przez W. Niesmiełowa. Dla niego, uwielbienie ludzkiej natury Jezusa i definitywne jej przyjęcie w pełnię Bożego życia sprawiło jednocześnie odnowienie i przemienienie całej natury ludzkiej. Według Niesmiełowa, każdy czlowiek, niezależnie od swego stanu moralnego posiada tę samą 
Pogłębiając myśl o antropologicznych wymiarach zmartwychwstania, Hryniewicz wyjaśnia, że Chrystus nie zmartwychwstał jako „wyizolowana jednostka i pojedyncza osoba, lecz jako Głowa całej ludzkości, która w przeciągu wieków ma stać się uczestnikiem Jego tajemnicy paschalnej. Dzięki temu właśnie zmartwychwstanie posiada powszechną, ogarniającą wszystkich ludzi wartość zbawczą (por. KK 22) i stanowi razem ze śmiercią istotną część misterium odkupienia". ${ }^{52}$ Jego powszechność stanowi konsekwencję zapoczątkowanej we wcieleniu, a uwieńczonej w misterium paschalnym solidarności Chrystusa z ludzkością. Hryniewicz wyjaśnia, że Chrystus stanął przed Ojcem nie sam, lecz jako ,pierwociny” nadchodzącego żniwa ludzkiego. Dlatego solidarne zespolenie Chrystusa z ludzkością wyraziło się nie tylko we wcieleniu i krzyżu, ale przede wszystkim w zmartwychwstaniu, które było przyjęciem ofiary Chrystusa jako ofiary całej ludzkości. W Chrystusie cała ludzkość powróciła już do Ojca i dzięki temu stała się zdolna do indywidualnego uczestnictwa w tym powrocie przez wiarę, sakramenty i całe życie chrześcijańskie. W takiej perspektywie odkupienie jawi się jako umieszczenie po prawicy Jezusa Chrystusa, w którym cała ludzkość uczestniczy jako w swym prototypie. W ten sposób, konkluduje Hryniewicz, w chwalebnym człowieczeństwie Chrystusa dokonało się już obiektywne odkupienie człowieka. Teraz ma się zrealizować subiektywnie w każdym chrześcijaninie, który umiera i zmartwychwstaje z Chrystusem do nowego życia. ${ }^{53}$ Realizuje się to wówczas, gdy osobowy wpływ człowieczeństwa Chrystusa oddziałuje skutecznie na każdego człowieka przez wiarę i sakramenty. On jest przejściem, przez które muszą przejść wszyscy, jeśli chcą osiągnąć spełnienie w Bogu - On jest paschą naszego zbawienia (por. 1 Kor 5,7). Wszystko, co dokonało

naturę, którą Chrystus poprzez zmartwychwstanie uwiecznił w sobie samym. Dzięki temu każdy czlowiek staje się „współistotny Chrystusowi” i staje się na zawsze członkiem Jego „wiecznego ciała"; por. tamże, s. 266; Pascha II, s. 51.

52 Pascha I, s. 447.

53 Por. tamże, s. 441. Hryniewicz rozróżnia odkupienie obiektywne wirtualne i odkupienie subiektywnie aktualne; zob. także H. U. v o n B a I t h a s a r, Wiarygodna jest tylko miłość, Kraków 1997, s. 36. Balthasar identycznie stwierdza, że na nic nie zda się całe obiektywne zbawienie, jeśli nie uobecni się subiektywnie jako współumieranie i wspólzmartwychwstanie z Chrystusem w Duchu Świętym. Również analizowana przez Lazaro Bustince myśl Jana Pawła II wyraża podobne sformułowania o subiektywnym uczestnictwie $\mathrm{w}$ misterium paschalnym Chrystusa; zob. L. B u s t i n c e, Tajemnica krzyża w życiu chrześcijańskim wedtug św. Jana od Krzyża i Jana Pawła II, w: M. C h m i e l e w s k i (red.), .. Najważniejsza jest miłość”. Księga Pamiq̨tkowa ku czci Księdza Profesora Waleriana Stomki, Lublin 1999, s. 215-225. 
się w Chrystusie, musi w jakiś sposób stać się także udziałem ludzkości. Jego człowieczeństwo jest trwałym przystępem do Boga. I tak stają się bardzo czytelne słowa zapisane w Księdze Apokalipsy: „Oto postawiłem w darze przed tobą drzwi otwarte, których nikt nie może zamknąć" (Ap 3,8).

\section{Wymiar pneumatologiczny}

Misterium paschalne jest objawieniem Trójjedynego Boga. Ojciec, dokonując zmartwychwstania swojego Syna, wprowadził w historię dziejów nowe prawo i nową moc, kierującą świat do ostatecznego spełnienia. Jest nim osobowa moc Ducha Świętego. Choć została wyraźnie objawiona światu $\mathrm{w}$ misterium Pięćdziesiątnicy, jest nierozerwalnie związana z całą tajemnicą Chrystusa. Zdaniem Hryniewicza, nie jest ważne to, że ich objawienie w historii jest oddzielone czasem, ponieważ Duch Święty jest transcendentny w stosunku do niego. Istnieje jedno misterium i jedna ekonomia, choć w percepcji ludzkiej dzieli się ona na poszczególne etapy. ${ }^{54}$ Taka jest bowiem logika objawienia trynitarnego.

Hryniewicz stwierdza, że od momentu wcielenia aż po zmartwychwstanie całe życie Jezusa przeniknięte było obecnością Ducha Świętego. ${ }^{55}$ To On uświęcił człowieczeństwo Chrystusa w momencie wcielenia, choć obecność ta była jeszcze zakryta przed ludzkimi oczami. Została zaś objawiona i udzielona światu już wraz z ostatnim tchnieniem Ukrzyżowanego. Hryniewicz argumentuje, że przebity bok, otwarte serce Jezusa i wypływająca zeń woda symbolizują otwarte dla wszystkich człowieczeństwo Zbawiciela, które staje się źródłem Ducha. ${ }^{56}$ W Piśmie Świętym Duch jest najczęściej określa-

${ }^{54}$ Podzielenie świąt - wyjaśnia Hryniewicz - zostało uwarunkowane historycznie i poddane liturgicznej ewolucji; por. Pascha II, s. 38.

ss Por. tamie, s. 63, 94; zob. J a n P a w eł II, Dominum et Vivificantem, Rzym 1986, nr 15-24; t e n ż e, Duch Święty w życiu Jezusa, w: t e n ż e, Wierzę w Ducha Świętego, Pana i Ożywiciela, Watykan 1992, s. 173-230.

${ }_{56}$ Objawienie staurologiczne to nie tylko aktywność Chrystusa i Ducha, ale, zdaniem Hryniewicza, także objawienie tajemnicy wspólcierpiącego Ojca, który przyjmuje na siebie cierpienie w osobie swojego Syna. Lubelski teolog nie zgadza się z interpretacjami przesadnie podkreślającymi napięcie i opuszczenie Syna przez Ojca w wydarzeniu krzyża, które proponują m.in. Balthasar i Moltmann. Polemizując z ich poglądami, stwierdza, że w osobie Syna Bóg sam stał się ofiarą. Tłumaczy, że w krytycznym momencie cierpienia i śmierci na krzyżu Ojciec i Syn pozostają całkowicie zjednoczeni, mimo że znaki Bożej obecności wydają się być ukryte. Doczesny wymiar krzyża jest sam w sobie niezrozumiały. Dlatego ostatecznym słowem Boga nie 
ny tymi właśnie terminami: „tchnienie” i „woda” (por. J 7, 10-15; Ap 21,6$).{ }^{57} \mathrm{~W}$ ten sposób śmierć jest początkiem życia. Zostaje to potwierdzone w wydarzeniu zmartwychwstania, którego Duch jest transcendentnym sprawcą. ${ }^{58}$ Choć teksty Nowego Testamentu przypisują wskrzeszenie Chrystusa przede wszystkim Ojcu, nie przeczy to aktywności Ducha. Boża moc jest jednocześnie przetwarzającą mocą Ducha. „Zmartwychwstanie jest z natury swej rzeczywistością nieodłączną od działania Ducha do tego stopnia, że zmartwychwstały Chrystus staje się «duchem ożywiającym» (1Kor 15, 45)." 59 To Duch przezwycięża panowanie śmierci w ciele Chrystusa i zapoczątkowuje nowy etap Jego istnienia, przemieniając Jego związek ze światem i stając się zasadą nowego życia. Dzięki Duchowi złożone w ofierze i zmartwychwstałe ciało Chrystusa stało się miejscem i przestrzenią, które zdolne jest ogarnąć całą ludzkość. On jest Tym, który ją gromadzi i urzeczywistnia dzieło zbawienia, objawiając i dopełniając obecność Chrystusa w wierzących i w świecie. ${ }^{60}$

Wcielenie, śmierć i zmartwychwstanie prowadzi zatem z konieczności do zstąpienia Ducha Świętego, który ukazuje do czego zmierzało uniżenie Chrystusa. Dzięki Duchowi, pisze Hryniewicz, Bóg staje się jeszcze bardziej Bogiem z n a m i. Duch objawia wiecznotrwałość Paschy d l a n a s i wprowadza ludzkość w rzeczywisty udział w Jego Boskim życiu. Zesłanie Ducha nie jest zatem przedłużaniem wcielenia, bo ono zakończyło się wraz z uwielbieniem Chrystusa. ${ }^{61}$

jest śmierć, ale zmartwychwstanie. To właśnie ono wypełnia sens krzyża i staje się potwierdzeniem obecności Boga w cierpieniu swego Syna; por. W. H r y n i e w i c z, Krzyż w misterium paschalnym Jezusa. Ku staurologii paschalno-eschatologicznej, AK 79(1987) z. 1, s. 22-37; Pascha I, s. 359; 410-411. Czasem ma się wrażenie, że to zdecydowane stanowisko Hryniewicza ,grzeszy" niekonsekwencją. Czerpiąc od Balthasara (zob. H. U. v o n B a I t h a s a r, Mysterium paschale, MySal 3/2, Einsiedeln 1969, s. 220) i Moltmanna (J. M o I t m a n n, Kirche in der Kraft des Geistes, München 1975, s. 11) pisze o Chrystusowym doświadczeniu bycia opuszczonym przez Ojca w chwili konania na krzyżu; zob. Pascha II, s. 84.

57 Por. Pascha I, s. 370; zob. także. A. J a n k o w s k i, Duch Dokonawca. Nowy Testament o posłannictwie eschatologicznym Ducha Świętego, Katowice 1983, s. 76-80.

58 Por. Pascha I, s. 355, Pascha II, s. 81.

59 Pascha I, s. 369; zob. także, G. L. M ü I l e r, Chrystologia - nauka o Jezusie Chrystusie, tłum. W. S z y m o n a, Kraków 1998, s. 238-240; J a n P a w e ł II, Duch Święty w zmartwychwstaniu Chrystusa, w: t e n ż e, Wierzę w Ducha Świętego, Pana i Ożywiciela, s. 227-230.

61) Por. Pascha II, s. 108-109. Na temat powszechnej obecności Ducha w świecie, umożliwiającej ludziom każdego czasu i miejsca dostęp do tajemnicy zbawienia zob. J. M c I n t y r e, The Shape of Pneumatology: Studies in the Doctrine of the Holy Spirit, Edinburgh 1997, s. 288-289; J. V. T a y I o r, The Go-Between God: The Holy Spirit and the Christian Mission, Philadelphia 1973, s. 180, 191.

61 Por. Pascha II, s. 68; Pascha I, s. 373. 
Wylanie Ducha w czasie Pięćdziesiątnicy jest nowym aktem Ojca, nieodłącznym od wydarzenia Chrystusa. Stanowi rozszerzenie tajemnicy zmartwychwstania, jej dopełnienie i zapoczątkowuje nową, eklezjalną wspólnotę życia ze Zmartwychwstałym, stanowiąc wydarzenie „ostatnich dni” i wprowadzając dzieje w czasy eschatologiczne. ${ }^{62}$

Hryniewicz podkreśla, że bez zstąpienia Ducha Świętego Pascha Chrystusa zostałaby pozbawiona swego wewnętrznego dynamizmu. To bowiem Duch sprawia, że Chrystus ma moc przekraczania barier czasu i przestrzeni, dosięgając każdego człowieka. Jest też zdania, że Pięćdziesiątnica bez Paschy utraciłaby swój sens. Samo mówienie o misterium Paschy i Pięćdziesiątnicy uznaje za nieścisłe, ze względu na spójnik ,i”. Pascha jest jednocześnie tajemnicą zstąpienia Ducha Świętego, a Jego wylanie jest uwarunkowane wydarzeniami paschalnymi. Dlatego wszelkie działanie Chrystusa dokonuje się w Duchu, a to, co czyni Duch, jest jednocześnie działaniem Chrystusa. To znaczy, że Syn i Duch są nieoddzielni zarówno w immanentnym życiu Boga, jak i w swoim zbawczym działaniu w świecie. ${ }^{63}$

Ta jedność jest szczególnie widoczna w nowym ciele Zmartwychwstałego, którym jest Kościół. Choć temat szerzej będzie omawiany w kolejnym rozdziale, już tutaj trzeba przytoczyć często powtarzane słowa Hryniewicza, że nie można oddzielać zbawczego działania Chrystusa oraz Ducha i tworzyć zeń jakichkolwiek monizmów. W ciągu historii znane są takie przypadki, jak choćby głoszenie specjalnej epoki Ducha przez Joachima da Fiore czy Adama Cieszkowskiego (na gruncie polskim). ${ }^{64}$ Lubelski dogmatyk z całą mocą wykazuje, że nie ma żadnej specjalnej epoki, ponieważ jest jedna ekonomia zbawienia. Można mówić o szczególnym działaniu Ducha, spełnianiu właściwego sobie posłannictwa, ale dokonuje się ono zawsze w relacji całkowitej wzajemności do Chrystusa. W ten sposób, to co wiąże się z Duchem Świętym ma jednocześnie odniesienie do Chrystusa, co nie przeszkadza doszukiwać się pewnych cech specyficznych. ${ }^{65}$

Próbując przedstawić tajemnicze działanie Ducha w ludzkich sercach, Hryniewicz przyznaje, że nie ma odpowiednich słów i pojęć, by je opisać. Posługując się dosadnym stwierdzeniem Balthasara, stwierdza, że pozostanie On Bogiem „Nieznanym po tamtej stronie

\footnotetext{
62 Por. tamże, s. 367.

63 Por. tamże, s. 372.

${ }_{64}$ Por. Pascha II, S. 99.

65 Por tamże, s. 102.
} 
Słowa". ${ }^{66}$ Zstąpienie Ducha na ludzkość jest zstąpieniem osobowym, choć niedostrzegalnym ludzkiemu oku. Jest nowym, wewnętrznym sposobem interwencji wśród ludzi przez osobową obecność. Nie jest to już obecność „,przed nami”, jak za ziemskiego życia Jezusa, lecz obecność „w nas”, czyli stan życia wewnętrznego. Ten nowy rodzaj obecności urzeczywistnia się przede wszystkim w Kościele, który jest szczególną przestrzenią Ducha. Chwalebne ciało Chrystusa jest całkowicie przeniknięte Jego mocą. Jest On nie tylko jego współtwórcą, ale w ogóle sprawia, że istnieje jako wydarzenie zbawcze. Jednocześnie, przenikając go od wewnątrz, pozostaje w stosunku do niego całkowicie suwerenny i transcendentny. Kościół w swej widzialnej postaci jest głównym, ale nie jedynym, narzędziem Ducha. Według znamiennych słów św. Ireneusza, które Hryniewicz przytacza, to nie widzialne granice Kościoła wyznaczają przestrzeń działania Ducha, ale Duch wyznacza obecność Kościoła, czyniąc wydarzenie zbawcze powszechnym.

W ten sposób Jego posłannictwo ma charakter misteryjny i eklezjalny. Polega ono przede wszystkim na jednoczeniu ludzi z Bogiem przez aktualizowanie i urzeczywistnianie w nich tego, czego raz na zawsze i prototypicznie dokonał Chrystus dla naszego zbawienia w misterium Paschy. ${ }^{67}$ Specyficzną cechą działania Ducha zdaniem Hryniewicza jest to, że posiada On szczególną relację do tajemnicy ludzkiego wnętrza i wolności, mając moc ich otwierania, wzywania $\mathrm{i}$ inspirowania. Dzięki temu misterium paschalne Chrystusa i wszystko, co On uczynił, nie należy do przeszłości, lecz staje się rzeczywistością uchwytną i dostrzegalną dla człowieka. By ukazać, w jaki sposób Duch Święty aktualizuje tajemnicę Paschy Chrystusa w ludziach, Hryniewicz przytacza znamienne, pełne prostoty i wymowy, słowa metropolity prawosławnego Ignacego z Lattaki: „W samej swojej osobie jest On Nowością działającą w świecie. On jest obecnością Boga-z-nami, «wspierającego swym świadectwem naszego ducha» $(\mathrm{Rz} 8,16)$. Bez Niego Bóg jest daleko, Chrystus należy do przeszłości, Ewangelia jest martwą literą, Kościół - zwyczajną organizacją, władza - dominacją, misja - propagandą, kult - wspomnieniem, a postępowanie chrześcijańskie - niewolniczą moralnością. Ale w Nim, poprzez nieodłączne ludzkie współdziałanie, świat dźwiga

66 Por. H. U. v o n B a I t h a s a r, Der Unbekannte jenseits des Wortes, w: H. K u h n (red.), Interpretation der Welt. Festgabe R. Guardini, Würzburg 1966, s. 638-645; cyt. za: Pascha II, s. 103.

67 Por. Pascha I, s. 374. 
się i jęczy w bólach porodu Królestwa, człowiek zmaga się przeciwko «ciału», Chrystus zmartwychwstały jest tuż obok, Ewangelia jest mocą kształtującą życie, Kościół znakiem wspólnoty trynitarnej, władza - wyzwalającą służbą, misja - Pięćdziesiątnicą, liturgia - uobecniającą anamnezą i antycypacją, działanie ludzkie doznaje łaski przebóstwienia". 68

To, co zostało niepowtarzalnie dokonane przez Chrystusa, staje się wiecznie aktualne dla człowieka, jeśli ten przyjmuje Boską ofertę i podejmuje wysiłek współpracy. W ten sposób Duch staje się dawcą jedności, uświęcenia i życia w Boskiej wspólnocie osób. On realizuje powrót człowieka do Boga, który stał się możliwy dzięki wydarzeniu Chrystusa. Droga zbawienia, która wiodła od Boga Ojca przez Syna do Ducha jest teraz dokładnie tą samą: człowiek dostępuje udziału w Bożym życiu nie inaczej jak dzięki Duchowi przez uczestnictwo w misterium Syna, a to oznacza komunię z Ojcem. Tak Chrystus okazuje się być drogą do Boga, a Duch Święty przewodnikiem na niej. On włącza człowieka w tajemnicę zbawienia, mianowicie w misterium Kościoła przez wiarę i sakramenty. W ten sposób Duch Święty obdarza ludzkość nową jakością życia oczyszczając ją, przebóstwiając i prowadząc ku świętości ${ }^{69}$ Duch otwiera na życie Zmartwychwstałego, „ofiarowując wszystkim możliwość dojścia w sposób Bogu wiadomy do uczestnictwa w tej paschalnej tajemnicy" (KDK 22). Proponując wszystkim ludziom dobrej woli życiodajne spotkanie ze Zmartwychwstałym, tworzy przez wolny udział człowieka wspólnotę Kościoła i wprowadza ją w czasy eschatologiczne. W ten sposób jednoczące działanie Ducha jest jednocześnie oczekiwaniem pełnego zmartwychwstania z Chrystusem i udziałem w życiu Trójcy. Dopełnieniem zmartwychwstania Chrystusa jest bowiem oczekiwane w nadziei zmartwychwstanie całej ludzkości, która już dokonuje się w teraźniejszości za sprawą Ducha, a w pełni urzeczywistni się w paruzji. ${ }^{70}$

${ }^{68}$ Cyt. za: Pascha II, s. 104; zob. także A. C z a j a, Problem pośrednictwa Ducha Świętego w posoborowej teologii, RT 51 (2004) z. 2, s. 65-77, zwł. s. 72.

69 Na temat przebóstwiającego iżyciodajnego działania Ducha Świętego zob. J a n Pa weł II, Wierzę w Ducha Świętego Pana i Ożywiciela; Y. Congar, Wierzę w Ducha Świętego. „Panem jest Duch i daje życie" (2Kor 3, 17), t. II, tłum. L. R u t o w s k a, Warszawa 1995, zwł. s. 124-137; Ch. S c h ö n b o r n, Przebóstwienie, życie i śmierć, tłum. W. S z y m o n a, Poznań 2001; Z. K i j a s, Przebóstwienie czlowieka $i$ świata, Kraków 2000.

70) Hryniewicz zauważa, że skład apostolski łączy wyznanie wiary w Ducha z rzeczywistością Kościoła, sakramentów i oczekiwaniem przyszłego spełnienia dziejów. Dlatego komponuje swoje rozważania właśnie o ten schemat. 
Integralne rozumienie misterium paschalnego Chrystusa stanowi mocny akcent w teologicznej twórczości Wacława Hryniewicza. Najczęstszym „grzechem” popełnianym przez teologów już od początków chrześcijaństwa jest przyznawanie bądź to śmierci, bądź to wcieleniu autonomicznej przyczynowości zbawczej. Tymczasem Hryniewicz podkreśla integralną i komplementarną perspektywę. Zapoczątkowana we wcieleniu Boga solidarność z ludzkością stanowi początek drogi, która trwała przez całe ziemskie życie Jezusa, punkt kulminacyjny osiągnęła na krzyżu, zaś wypełnienie uzyskała w momencie zmartwychwstania i zesłania Ducha Świętego. W uwielbionym człowieczeństwie Chrystusa cała ludzkość powróciła już do Ojca i dzięki temu stała się zdolna do indywidualnego uczestnictwa w tym powrocie przez wiarę, sakramenty i życie chrześcijańskie. Uwielbienie Jezusa wprowadziło ludzkość w zupełnie nowy rodzaj egzystencji, który od tego momentu jest całkowicie poddany uświęcającemu działaniu Ducha Świętego. On jest tym, który dokonuje kontynuacji Chrystusowego dzieła, powierzonego wspólnocie Kościoła i w ten sposób umożliwia każdemu człowiekowi udział w wiecznie trwałym misterium Paschy. 